\title{
Hubungan Pengetahuan, Sikap, Dan Perilaku Wanita Dewasa Muda Terhadap Kanker Leher Rahim
}

\author{
Lely Safrina, Kartika Sari, Marty Mawarpury \\ safrina_lely@yahoo.com
}

\section{Program Studi Psikologi, Fakultas Kedokteran, Universitas Syiah Kuala, Banda Aceh, Indonesia}

Penelitian ini bertujuan untuk mengetahui hubungan pengetahuan, sikap, dan perilaku wanita dewasa muda terhadap kanker leher rahim. Survei yang melibatkan 5.423 perempuan di Asia dan dilakukan pada sembilan negara termasuk Indonesia, menunjukkan hanya $2 \%$ perempuan yang mengetahui Human Papiloma Virus (HPV) merupakan penyebab kanker leher rahim. Rendahnya tingkat pengetahuan diduga memperburuk kondisi dan kasus kanker leher rahim terus meningkat setiap tahunnya. Menggunakan pendekatan kuantitatif dengan metode survei, penelitian ini dilakukan di kota Banda Aceh dengan karakteristik responden adalah wanita dewasa muda, berusia 22-30 tahun dan belum aktif secara seksual. Pengambilan data menggunakan kuesioner tentang pengetahuan, sikap, dan perilaku terhadap kanker leher rahim. Responden dalam penelitian ini berjumlah 269 orang. Hasil penelitian ini menunjukkan bahwa, 1) pengetahuan perempuan terhadap kanker leher rahim cukup karena tidak terpapar dengan informasi tentang kanker leher rahim secara maksimal, 2) sikap responden terhadap kanker leher rahim tergolong positif. Hal ini dapat disebabkan oleh pengetahuan yang cukup, namun perilaku terhadap kanker leher rahim belum sesuai dengan perilaku pencegahan kanker leher rahim.

Kata Kunci: Pengetahuan, Sikap, Wanita Muda, Kanker Leher Rahim

Kanker adalah penyakit dari pertumbuhan tidak normal sel-sel jaringan tubuh yang berubah menjadi sel kanker. Dalam perkembangannya, sel-sel kanker dapat menyebar ke bagian tubuh lainnya sehingga dapat menyebabkan kematian. Di Indonesia, prevalensi penyakit kanker cukup tinggi. Berdasarkan data tahun 2013 (Badan Penelitian dan Pengembangan, 2013), prevalensi tumor/kanker di Indonesia adalah 1,4 per 1.000 penduduk, atau sekitar 330.000 orang. Kanker ter- 
tinggi di Indonesia pada perempuan adalah kanker payudara dan kanker leher rahim. Menurut Ferlay, dkk. (2014), berdasarkan estimasi Globocan, International Agency for Research on Cancer (IARC), insiden kanker payudara sebesar 40 per 100.000 perempuan, kanker leher rahim 17 per 100.000 perempuan, kanker paru 26 per 100.000 laki-laki, dan kanker kolorektal 16 per 100.000 laki-laki. Berdasarkan data Sistem Informasi Rumah Sakit Tahun 2010, kasus rawat inap kanker payudara sebesar 12.014 kasus $(28,7 \%)$ dan kanker leher rahim 5.349 kasus $(12,8 \%)$.

Kanker leher rahim merupakan kanker yang mematikan tidak hanya di Indonesia tetapi juga di beberapa negara lainnya. Seperti di Australia, 85\% perempuan meninggal dunia dikarenakan kanker leher rahim, sedangkan di Malaysia Kanker leher rahim merupakan kanker kedua yang mematikan. Menurut Wong, dkk. (2009), angka kematian rata-rata perempuan dikarenakan kanker leher rahim pada tahun 1996-2000 berkisar 0,29\%-0,41\%. Menurut Abotchie dan Shokar (2009) di Inggris, kanker leher rahim merupakan kanker kelima yang mematikan. Lebih lanjut Abotchie dan Sokar juga menemukan bahwa kanker leher rahim merupakan kanker yang paling sering dialami perempuan Afrika. Menurut WHO (dalam Abotchie dan Sokar, 2009) perempuan mengidap kanker leher rahim 29,3/100.000 lebih tinggi lima kali lipat dibandingkan di Amerika Serikat dan angka kematian diakibatkan oleh kanker leher rahim 23,8/100.000 perempuan yang berarti sepuluh kali lipat lebih tinggi dibandingkan di Amerika Serikat.

Kejadian kanker serviks lebih tinggi pada negara berkembang. Kebanyakan wanita dengan kanker serviks biasanya terlambat ke rumah sakit, tidak seperti di negara-negara maju yang sebagian besar wanita memiliki kesadaran tentang penyakitnya sehingga harapan untuk sembuh juga tinggi. Hal ini sebagian disebabkan oleh faktor pendidikan dan pemberdayaan perempuan. Vail-Smith dan White (1992) menemukan bahwa kurangnya pengetahuan HPV, ditambah dengan persepsi yang salah tentang kerentanan, berdampak pada sikap dan perilaku mahasiswa wanita mengenai pencegahan kanker serviks. Penelitian ini juga menyimpulkan bahwa $72 \%$ mahasiswa perempuan di sebuah studi di Amerika belum pernah mendengar tentang infeksi HPV dan tidak menyadari risiko kanker serviks terkait. Sebuah studi serupa yang dilakukan pada mahasiswa Vietnam menemukan bahwa lebih dari sepertiga $(39,3 \%)$ responden yang aktif secara seksual dilaporkan pernah melakukan Pap smear (Yi, 1998).

Tingginya angka kematian yang disebabkan kanker leher rahim dapat dicegah apabila wanita dewasa muda memiliki pengetahuan dan menyadari bahwa kanker leher rahim merupakan salah satu penyakit yang mematikan. Namun, dikarenakan oleh kurangnya pengetahuan mengenai faktor risiko sehingga wanita dewasa muda tidak merasa perlu untuk melakukan skirining (Klug, dkk., 2005). Lebih lanjut dijelaskan bahwa rendahnya tingkat pengetahuan akan mempengaruhi wanita dewasa muda untuk melakukan skirining kanker leher rahim (Juon, dkk., 2002; Juon, dkk., 2003; Kim, dkk., 1999, dalam Lee, dkk., 2008).

Ironisnya, pengetahuan wanita dewasa muda masih rendah mengenai kanker leher rahim, tidak jauh berbeda dengan pengetahuan tenaga kesehatan yaitu $49 \%$ dokter dan $56,6 \%$ bidan memiliki pengetahuan yang rendah mengenai kanker 
leher rahim (Fauziah, dkk., 2011). Penelitian lainnya menemukan bahwa terdapat hubungan antara rendahnya kemampuan literasi kesehatan dan pengetahuan akan berdampak pada sikap negatif terhadap skrining kanker leher rahim (Dolan, dkk., 2004). Menurut Notoatmodjo (2003) pengetahuan merupakan hasil dari tahu dan ini terjadi setelah melakukan penginderaan terhadap suatu objek tertentu. Pengetahuan adalah domain kognitif yang sangat penting untuk tindakan seseorang. Pengetahuan mencakup domain kognitif yang memiliki enam tingkatan yaitu tahu (know), memahami (comprehension), aplikasi (application), analisis (analysis), sintesis (syntesis), dan evaluasi (evaluation). Perilaku kesehatan adalah suatu respon seseorang terhadap stimulus atau objek yang berkaitan dengan sakit atau penyakit, sistem pelayanan kesehatan, makanan, minuman, serta lingkungan.

Perilaku kesehatan dapat diklasifikasikan menjadi tiga kelompok (Notoadmidjo, 2003):

1. Perilaku pemeliharaan kesehatan (health maintenance), adalah perilaku atau usaha-usaha seseorang untuk menjaga atau memelihara kesehatan agar tidak sakit dan usaha untuk penyembuhan apabila sakit.

2. Perilaku pencarian atau penggunaan sistem atau fasilitas kesehatan yang disebut juga perilaku mencari bantuan kesehatan (help seeking behavior). Perilaku ini menyangkut upaya dan tindakan seseorang pada saat menderita penyakit.

3. Perilaku kesehatan lingkungan, yaitu apabila seseorang merespon lingkungan baik lingkungan fisik, maupun sosial budaya.
Menurut Meliono (2007), pengetahuan dipengaruhi oleh beberapa hal yaitu pendidikan, media, dan keterpaparan informasi. Menurut Sarwono (2002), sikap adalah kesiapan pada seseorang untuk bertindak secara tertentu terhadap hal-hal tertentu. Ajzen (1988) mendefinisikan sikap sebagai predisposisi yang dipelajari individu untuk memberikan respon suka atau tidak suka secara konsisten terhadap objek sikap. Respon suka atau tidak suka itu adalah hasil proses evaluasi terhadap keyakinan-keyakinan (beliefs) individu terhadap objek sikap (Fishbein dan Ajzen, 1975). Baron dan Byrne (2004) mendefinisikan sikap sebagai penilaian subjektif seseorang terhadap suatu objek. Sikap adalah respon evaluatif yang diarahkan seseorang terhadap orang, benda, peristiwa, dan perilaku sebagai objek sikap. Sikap melibatkan kecenderungan respon yang bersifat preferensial. Sikap sebagai respon evaluatif menunjukkan ekspresi suka atau tidak suka, setuju atau tidak setuju, mendekati atau menghindari, dan tertarik atau tidak tertarik terhadap objek sikap.

Sikap dapat bersifat positif dan negatif (Purwanto, 1998), yaitu:

1. Sikap positif, kecenderungan tindakan adalah mendekati, menyenangi, dan mengharapkan objek tertentu.

2. Negatif, kecenderungan tindakan untuk menjauhi, menghindari, dan tidak menyukai objek tertentu.

Selain itu, sikap memiliki ciri tertentu, yaitu:

1. Sikap bukan bawaan lahir melainkan dipelajari atau dibentuk sepanjang perkembangan hidup dalam hubungan dengan objek.

2. Sikap tidak berdiri sendiri tetapi berhubungan dengan suatu objek. 
3. Objek sikap merupakan satu atau beberapa hal yang merupakan kumpulan dari sesuatu.

Perilaku merupakan respon atau reaksi seseorang terhadap stimulus (rangsangan dari luar). Perilaku ini terjadi melalui proses adanya stimulus terhadap organisme dan kemudian organisme tersebut merespon. Secara khusus, perilaku kesehatan menurut Notoatmodjo (2003) adalah suatu respon seseorang (organisme) terhadap stimulus atau objek yang berkaitan dengan sakit atau penyakit, sistem pelayanan kesehatan, makanan, danminuman, serta lingkungan. Dari batasan ini, perilaku kesehatan dapat diklasifikasikan menjadi tiga kelompok:

1. Perilaku pemeliharaan kesehatan (health maintenance), merupakan perilaku atau usaha-usaha seseorang untuk memelihara atau menjaga kesehatan agar tidak sakit dan usaha untuk penyembuhan bilamana sakit.

2. Perilaku pencarian pengobatan (health seeking behavior) atau perilaku penggunaan sistem atau fasilitas kesehatan. Perilaku ini berkaitan dengan upaya atau tindakan seseorang pada saat menderita penyakit dan atau kecelakaan untuk mencari dan memanfaatkan sarana dan prasarana kesehatan yang tersedia.

3. Perilaku kesehatan lingkungan yang berkaitan dengan respons seseorang terhadap lingkungan, baik lingkungan fisik maupun sosial budaya dan sebagainya.

Kanker leher rahim adalah penyakit yang dihasilkan dari genotype risiko tinggi dari transmisi HPV secara seksual, baik pada pasangan, intercourse usia muda, dan perilaku seksual pasangan. Hal ini menyebabkan tingginya risiko perempuan terhadap paparan HPV dan berkembangnya sel kanker (Vanslyke, dkk., 2008).

Tingginya angka penderita kanker leher rahim dapat dikarenakan oleh berbagai faktor, di antaranya adalah Human Papiloma Virus (HPV), hubungan seksual yang dilakukan pada usia dini, seringnya berganti pasangan seksual, dan perilaku seksual pasangan. Namun, dari beberapa faktor tersebut, $95 \%$ penyebab utama kanker leher rahim dikarenakan oleh HPV yang ditularkan melalui kontak kulit. Walaupun penggunaan kondom dapat menurunkan kemungkinan tertularnya HPV, namun kondom tidak mampu melindungi sepenuhnya resiko tertularnya HPV.

Berdasarkan penjelasan di atas, terlihat bahwa tingginya resiko perempuan terhadap paparan HPV dan peluang berkembangnya sel kanker. Fakta menyebutkan bahwa penyakit kanker leher rahim ini dapat dicegah dengan skrining. Meskipun pelayanan gratis skrining kanker serviks sudah tersedia di rumah sakit pemerintah, namun faktor-faktor yang mempengaruhi keinginan untuk melakukan skrining masih belum diketahui secara jelas. Oleh karena itu, penelitian ini tertarik untuk melihat hubungan pengetahuan, sikap, dan perilaku wanita dewasa muda terhadap kanker leher rahim. Adapun hipotesis penelitian ini adalah wanita yang memiliki pengetahuan lebih mengenai resiko kanker leher rahim dan wanita yang memiliki sikap positif akan melakukan skrining.

\section{Metode}

Penelitian ini menggunakan pendekatan kuantitatif dengan metode survei. Sampel merupakan wanita usia muda berjumlah 269 orang yang diminta untuk mengisi kuesioner tentang kanker leher rahim. 
Pengumpulan data dilakukan di Banda Aceh, selama empat minggu pada bulan Agustus 2014. Responden merupakan wanita yang berada pada rentang usia 1622 tahun.

Kuesioner yang digunakan dalam penelitian ini merupakan adopsi dari kuesioner yang telah digunakan oleh John (2011) di Tanzania. Pengukuran kuesioner terbagi atas empat bagian, yaitu: 1) informasi responden (sosio-demografi), 2) pengetahuan tentang kanker leher rahim dan skriningnya, 3) sikap terhadap skrining kanker leher rahim, dan 4) perilaku terhadap skrining kanker leher rahim.

Tabel 1.

Demografi Responden.

\begin{tabular}{|c|c|c|c|}
\hline $\begin{array}{c}\text { Karakteristik } \\
\text { responden }\end{array}$ & Range & Jumlah & $\%$ \\
\hline \multirow[t]{3}{*}{ Usia } & $16-18$ & 98 & 36,70 \\
\hline & $19-22$ & 161 & 60,0 \\
\hline & $\begin{array}{l}\text { Tidak ada } \\
\text { informasi }\end{array}$ & 8 & 3.00 \\
\hline Jenis kelamin & Perempuan & 267 & 100 \\
\hline \multirow[t]{5}{*}{ Pendidikan } & SMA & 8 & 3,00 \\
\hline & D3 & 12 & 4,49 \\
\hline & $\mathrm{S} 1$ & 246 & 92,13 \\
\hline & Tidak Ada & & \\
\hline & Informasi & 1 & 0,37 \\
\hline \multirow{3}{*}{ Status } & Lajang & 266 & 99,63 \\
\hline & Tidak ada & & \\
\hline & informasi & 1 & 0,37 \\
\hline \multirow[t]{14}{*}{ Daerah Asal } & Abdya & 10 & 3,75 \\
\hline & Aceh & 8 & 3,00 \\
\hline & Aceh Besar & 14 & 5,24 \\
\hline & Aceh Jaya & 1 & 0,37 \\
\hline & Aceh & & \\
\hline & Selatan & 24 & 8,99 \\
\hline & Singkil & 3 & 1,12 \\
\hline & Aceh & & \\
\hline & Tamiang & 9 & 3,37 \\
\hline & Aceh & & \\
\hline & Tengah & 6 & 2,25 \\
\hline & Aceh Timur & 17 & 6,37 \\
\hline & Aceh Utara & 42 & 15,73 \\
\hline & Banda Aceh & 50 & 18,73 \\
\hline
\end{tabular}

\begin{tabular}{llrr}
\hline $\begin{array}{c}\text { Karakteristik } \\
\text { responden }\end{array}$ & Range & Jumlah & $\%$ \\
\hline & Bener & 8 & 3,00 \\
& Meriah & 10 & 3,75 \\
& Bireun & 4 & 1,50 \\
& Gayo Lues & 16 & 5,99 \\
& Aceh Barat & 4 & 1,50 \\
& Pidie & 5 & 1,87 \\
& Pidie Jaya & 10 & 3,75 \\
& Sabang & 23 & 8,61 \\
& Luar Aceh & & \\
& Tidak ada & 3 & 1,12 \\
\hline
\end{tabular}

\section{Hasil}

Sebanyak 269 responden melengkapi kuesioner. Rata-rata usia responden berkisar 19-22 tahun (60\%) dan seluruh responden berstatus lajang. Sementara itu, mayoritas responden berstatus mahasiswa program sarjana $(92,13 \%)$.

Tabel 2.

Distribusi tingkat pengetahuan, sikap dan perilaku terhadap kanker leher rahim.

\begin{tabular}{|c|c|c|}
\hline Variabel & Jumlah & $\%$ \\
\hline Pengetahuan & $\mathrm{N}=269$ & \\
\hline Baik & 107 & 39,8 \\
\hline Rata-rata & 72 & 26,8 \\
\hline Buruk & 90 & 33,5 \\
\hline Sikap & $\mathrm{N}=232$ & \\
\hline Positif & 151 & 65,09 \\
\hline Negatif & 81 & 34,91 \\
\hline Perilaku & & \\
\hline Good practice & 278 & 95.91 \\
\hline No Practice & 11 & 4.09 \\
\hline $\begin{array}{l}\text { Alasan untuk tidak } \\
\text { melakukan skrining }\end{array}$ & $\mathrm{N}=269$ & \\
\hline a. Mungkin menyakitkan & 20 & 7,43 \\
\hline b. Saya merasa malu & 8 & 2,97 \\
\hline c. Saya merasa sehat & 36 & 13,38 \\
\hline $\begin{array}{l}\text { d. Suami saya tidak akan } \\
\text { setuju }\end{array}$ & 0 & 0 \\
\hline $\begin{array}{l}\text { e. Saya takut ketika dites } \\
\text { malah ketahuan terkena } \\
\text { kanker leher rahim }\end{array}$ & 16 & 5,59 \\
\hline f. Biayanya mahal & 18 & 6,69 \\
\hline $\begin{array}{l}\text { g. Saya tidak tahu tentang } \\
\text { skrining ini }\end{array}$ & 99 & 36,80 \\
\hline h. Saya belum memutuskan & 63 & 23,42 \\
\hline i. Lainnya & 15 & 5,58 \\
\hline
\end{tabular}


Tabel 3.

Distribusi respon sikap terhadap kanker leher rahim.

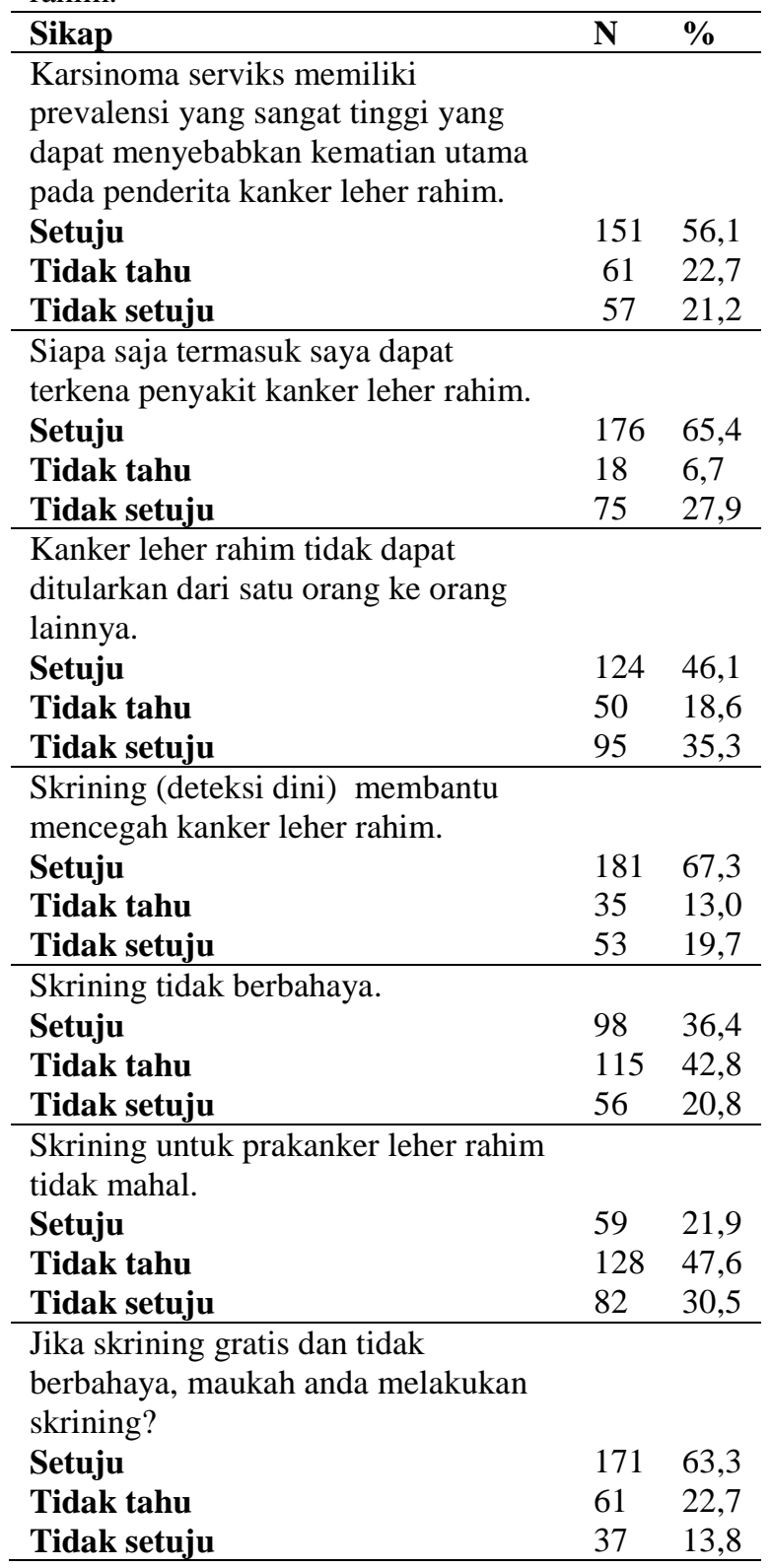

Tabel 4.

Sumber informasi tentang kanker bagi responden.

\begin{tabular}{lcc}
\hline \multicolumn{1}{c}{ Sumber } & $\begin{array}{c}\text { Frekuensi } \\
(\mathbf{n})\end{array}$ & Persen \\
\hline Media & 206 & 76,58 \\
$\begin{array}{l}\text { Brosur, poster, dan bahan } \\
\text { bacaan lainnya }\end{array}$ & 114 & 42,38 \\
$\begin{array}{l}\text { Petugas atau tenaga } \\
\text { kesehatan }\end{array}$ & 56 & 20,82 \\
$\begin{array}{l}\text { Keluarga, teman, tetangga, } \\
\text { dan rekan-rekan kerja }\end{array}$ & 98 & 36,43 \\
$\begin{array}{l}\text { Pemimpin agama } \\
\text { Guru }\end{array}$ & 3 & 1,12 \\
Lainnya (jelaskan) & 81 & 30,11 \\
& 3 & 1,12 \\
\hline
\end{tabular}

Perilaku deteksi kanker serviks

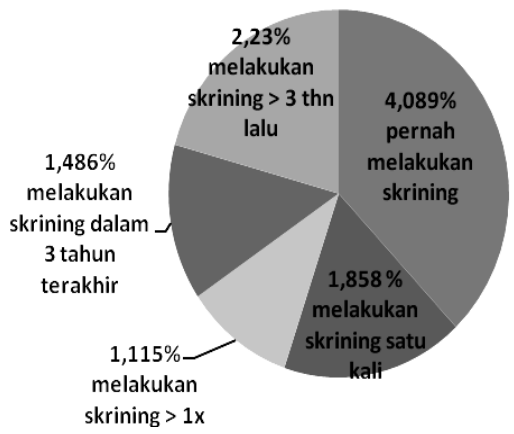

Gambar 1. Perilaku deteksi kanker leher rahim.

Berdasarkan hasil penelitian, beberapa alasan mengapa responden tidak melakukan skrining kanker leher rahim dapat dilihat pada gambar berikut:

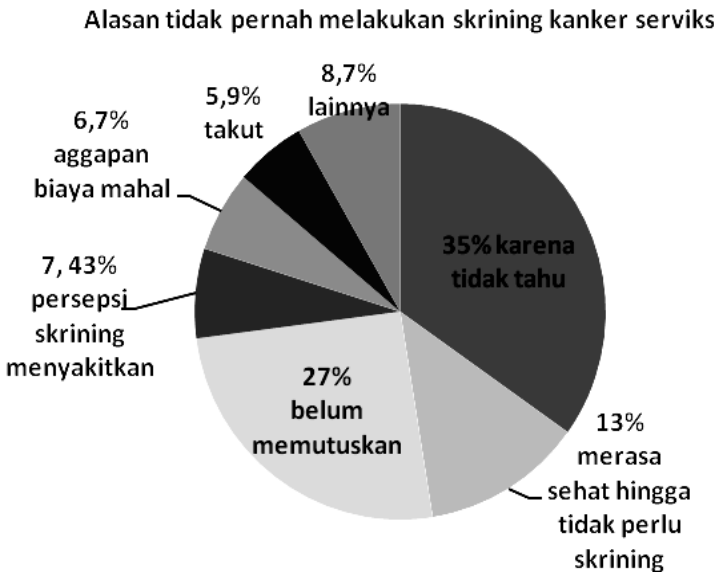

Gambar 2. Alasan tidak pernah melakukan skrining kanker leher rahim.

\section{Diskusi}

Pengetahuan terhadap Kanker Leher Rahim

Hasil penelitian ini menunjukkan bahwa tingkat pengetahuan responden terhadap kanker leher rahim baik $(39,8 \%)$, meskipun secara statistik, jumlah responden dengan pengetahuan rendah terhadap kanker leher rahim $(33,5 \%)$ tidak jauh berbeda dengan tingkat penegtahuan yang baik. Menurut Meliono (2007), pengetahuan dipengaruhi oleh beberapa 
hal yaitu pendidikan, media, dan keterpaparan informasi. Partisipan dalam penelitian ini adalah mahasiswa Universitas Syiah Kuala yang sedang melanjutkan studi di perguruan tinggi. Jika dilihat dari tingkat pendidikannya maka wajar jika partisipan memiliki tingkat pengetahuan yang baik dan memuaskan tentang kanker leher rahim. Hal lainnya juga dapat dilihat bahwa sebagian besar responden telah terpapar media terkait informasi mengenai kanker leher rahim (76,58\%). Namun demikian, hampir sebagian besar responden tidak mengetahui tentang screening tes kanker leher rahim. Oleh karena itu, dapat disimpulkan bahwa informasi tentang kanker leher rahim yang diperoleh responden masih kurang menyeluruh.

\section{Sikap dan Perilaku terhadap Kanker Leher Rahim}

Secara umum, sikap responden terhadap kanker leher rahim dalam penelitian ini positif $(65,09 \%)$, artinya sejalan dengan pengetahuan yang baik, maka sikap juga cenderung positif. Dunia modern meningkatkan harapan hidup individu, perubahan dramatis di lingkungan kerja yang menekankan gaya hidup sehat (Curtis, 2000). Hal ini memberikan pandangan bahwa sehat itu sangat bernilai dan dapat diperoleh oleh siapapun (Curtis, 2000). Oleh karena itu, sikap positif partisipan terhadap kanker leher rahim dapat diartikan sebagai suatu evaluasi positif mengenai hal-hal yang berkaitan dengan kanker leher rahim agar terhindar dari penyakit kronis ini. Satu hal yang menjadi perhatian adalah responden belum cukup terpapar informasi mengenai skrining kanker leher rahim. Sebanyak $42,8 \%$ responden tidak mengetahui bahwa skrining kanker leher rahim tidak berbahaya, yang sejalan dengan ketidaktahuan menjadi penyebab tidak pernah melakukan deteksi/skrining kanker leher rahim (35\%). Kurangnya pengetahuan berimplikasi pada strategi untuk mencegah kanker leher rahim dengan vaksin HPV (Abotchie dan Shokar, 2009). Health Belief Model menyebutkan bahwa masyarakat akan terikat dengan perilaku mencari bantuan kesehatan jika mereka menerima manfaat terhadap dirinya. Hal ini sejalan dengan temuan penelitian yang dilakukan oleh Fylan (1998), yang menyebutkan bahwa alasan terbesar perempuan tidak melakukan skrining dikarenakan minimnya pengetahuan mengenai skrining, skrining tidak memberikan manfaat, merasa sehat, merasa takut, dan skrining akan menyakitkan. Abotchie dan Shokar (2009) juga menemukan bahwa alasan responden tidak melakukan skrining karena merasa skrining akan menyakitkan. Menurut McMullin, dkk. dalam Can (2010) menyatakan bahwa salah satu prediktor untuk menjadikan layanan kesehatan memiliki fasilitas yang kuat adalah dengan adanya asuransi kesehatan. Perempuan yang difasilitasi dengan asuransi kesehatan akan memiliki sikap yang positif untuk melakukan skrining. Lebih lanjut dijelaskan bahwa adanya ketersediaan asuransi kesehatan merupakan sebuah cara yang efektif untuk meningkatkan strategi pencegahan terhadap kanker leher rahim.

Hasil dari penelitian ini didukung oleh sejumlah penelitian yang menyebutkan bahwa beberapa hambatan terhadap skrining kanker leher rahim adalah kurangnya kesadaran akan pentingnya pemeriksaan dini kanker leher rahim, tidak memadainya akses pada pelayanan kesehatan, ketidaknyamanan terhadap proses skrining, ketakutan terhadap hasil skrining kanker leher rahim. Selain itu, adanya hambatan waktu untuk melakukan skrining serta budaya dan kepercayaan tradisional tentang peran sosial juga mempengaruhi respons terhadap kanker leher rahim. Namun pengetahuan dan keyakinan terhadap pap smear menjadi 
prediktor terkuat terhadap pengulangan skrining (Wong, dkk., 2009; Abotchie dan Shokar, 2009). Hal ini menunjukkan bahwa petugas kesehatan pada layanan primer seperti perawat kesehatan masyarakat menjadi bagian penting dari program yang bertujuan meningkatkan jumlah skrining kanker leher rahim.

Namun demikian, model perubahan perilaku juga dipengaruhi oleh peran dari perbedaan individu (individual references) dalam perilaku dan tahapan dari decision making serta decision taking terkadang tidak selalu sesuai dengan logika dan pemikiran rasional (Curtis, 2000). Oleh karena itu, sangat mungkin hambatan seseorang untuk melakukan skrining tes adalah karena takut, biaya besar, merasa sehat dan sebagainya. Selain itu, usia mempengaruhi responden untuk melakukan skrining terhadap kanker leher rahim. Dalam penelitian ini, usia responden yang berkisar antara 16-22 tahun tergolong remaja yang merasa belum perlu untuk melakukan skrining. Lyimo dan Beran (2012) menyatakan bahwa keinginan untuk melakukan skrining tergolong rendah pada wanita yang berusia 20-29 tahun dan 60 tahun ke atas. Lebih lanjut Lyimo dan Beran menjelaskan bahwa wanita single dan janda akan memiliki keinginan lebih rendah untuk melakukan skrining dibandingkan wanita yang sudah menikah.

Beberapa keterbatasan penelitian ini yaitu, peneliti hanya mendapatkan data kuantitatif, sehingga tidak bisa menggambarkan dinamika hubungan bahwa adanya pengetahuan yang tidak selalu berimplikasi pada praktek manajemen kesehatan seperti skrining tes untuk kanker leher rahim.

\section{Kesimpulan}

1. Pengetahuan perempuan terhadap kanker leher rahim cukup baik, namun informasi tentang kanker leher rahim belum didapatkan secara menyeluruh, misalnya tentang skrining kanker leher rahim.

2. Sikap responden terhadap kanker leher rahim tergolong positif. Hal ini dapat disebabkan oleh pengetahuan yang cukup, namun perilaku terhadap kanker leher rahim belum sesuai dengan perilaku pencegahan kanker leher rahim.

\section{Rekomendasi}

1. Mengingat tingginya angka kematian wanita dewasa muda, pemerintah perlu membuat langkah strategis untuk dapat meningkatkan pengetahuan wanita dewasa muda. Di antaranya adalah dengan memasukkan kanker serviks menjadi salah satu program MDGs.

2. Dinas kesehatan perlu meningkatkan promosi dan psikoedukasi mengenai kanker leher rahim. Usaha ini harus sejalan dengan peningkatan pengetahuan tenaga kesehatan sebagai agent of change.

3. Pemerintah perlu memasukkan skrining terhadap kanker serviks dalam asuransi kesehatan, sehingga keinginan perempuan untuk melakukan skrining akan lebih tinggi yang nantinya akan dapat menurunkan angka kematian akibat kanker leher rahim.

4. Mengaktifkan layanan Puskesmas sebagai pusat layanan dasar dalam memberikan promosi dan psikoedukasi mengenai kanker leher rahim. 


\section{Daftar Pustaka}

Abotchie, N. P. \& Shokar K. N. (2009). Cervical cancer screening among college students in Ghana: Knowledge and health beliefs International Journal Gynecology Cancer, 19(3), 1-10.

Azjen, I. (1988). Attitudes, Personality, and Behavior. Milton-Keynes: Open University Press.

Badan Penelitian dan Pengembangan. (2013). Riset Kesehatan Dasar. Jakarta: Kementerian Kesehatan RI.

Baron, R. A. \& Bryne, D. (2004). Psikologi Sosial (Edisi 10) Jilid 1. Jakarta: Erlangga.

Can, G. (2010). Mailand Chinese women's perception of risk of cervical cancer: A model to understand factors determining cervical screening behaviour. Thesis. The Chinese University of Hong Kong.

Curtis, A. J. (2000). Health Psychology. London: Routledge.

Dolan, N. C., Ferreira, M. R., Davis, T. C., Fitzgibbon, M. L., Rademaker, A., Liu, D., Schmitt, B. P., Gorby, N., Wolf, H., \& Bennett, C. L. (2004). Colorectal cancer screening knowledge, attitudes, and beliefs among veterans: Does literacy make a difference? Journal of Clinical Oncology, 22(13), 2617-2622.

Fauziah, R. M., Wirawan, J. P., Lorianto, R., Utari, A. P., Cahyanur, R., \& Budiningsih, R. (2011). Deteksi dini kanker leher rahim pada pusat pelayanan primer di lima wilayah DKI Jakarta. Artikel Penelitian. Fakultas Kedokteran Universitas Indonesia, Jakarta.

Ferlay, J., Soerjomataram I., Dikshit, R., Eser, S., Mathers, C., Rebelo, M., Parkin, D. M., Forman, D., \& Bray, F. (2014). Cancer incidence and mortality worldwide: Sources, methods, and major pattern in GLOBOCAN 2012. International Journal of Cancer, 136(5), 359-386.
Fishbein, M. \& Azjen , I. (1975). Belief, attitude, intention, and behavior: An introduction to theory and research. Diunduh melalui http://people. umass.edu/aizen/f\&a1975.html.

Fylan, F. (1998). Screening for cervical cancer: A review of women's attitudes, knowledge, and behaviour. British Journal of general practice, 48, 1509-1514.

John, J. (2011). The kowledge, attitudes, practice and perceived barriers towards screening for premalignant cervical lession among women aged 18 years and above in Songea urban Ruvuma. Dissertation. Muhimbili University of Health and Allied Sciences.

Klug, S. J., Hetzer, M., \& Blettner, M. (2005). Screening for breast and cervical cancer in a large German city: Participation, motivation, and knowledge of risk factor. European Journal of Public Health, 15(1),7077.

Lee, E. E., Fogg, L., \& Menon, U. (2008). Knowledge and beliefs related to cervical cancer and screening among Korean American women. West Journal of Nursing Research, 30(8), 960-974.

Lyimo, F. \& Beran, T. N. (2012). Demographic, knowledge, attitudinal, and accessibility factors associated with uptake of cervical cancer screening among women in rural district of Tanzania: Three public policy implication. Research Article. BMC Public Health.

Meliono, I. (2007). Pengetahuan - MPKT Modul 1. Jakarta: Lembaga Penerbit FEUI.

Notoadmodjo, S. (2003). Pendidikan dan Perilaku Kesehatan. Jakarta: Rieneka Cipta.

Purwanto, H. (1998). Pengantar Perilaku Manusia untuk Keperawatan. Jakarta: EGC. 
Sarwono, S. W. (2002). Individu dan Teori-teori Psikologi Sosial. Jakarta: Balai Pustaka.

Vail-Smith K. \& White, D. M. (1992). Risk level, knowledge, and preventive behavior of human papillomavirus among sexually active college women. Journal of American Colegel Health, 40, 227230.

Vanslyke, G. J., Baum, J., Plaza, V., Otero, M., Wheeler, C., \& Helitzer, D. (2008). HPV and cervical cancer testing and prevention: Knowledge, belief, and attitudes among Hispanic women. Qualitative Health Research, 1-13.

Wong, L. P., Wong, Y. L., Low, W. Y., Khoo, E. M., \& Shuib, R. (2009). Knowledge and awareness of cervical cancer and screening among Malaysian women who have never had a pap smear: A qualitative study. Singapore Medical Journal, 50(1), 49-53.

Yi, J. K. (1998). Acculturation and pap smear screening practices among college-aged Vietnamese women in the United States. Cancer Nursing, 21, 335-341. 